\title{
Determination of Geothermal Energy Sources in Masu Area Northeastern Nigeria Using Spectral Analysis of Aeromagnetic Data
}

\author{
Moses Akiishi, Bernadette Chidomnso Isikwue*, Alexander Aondongu Tyovenda \\ Department of Physics, Federal University of Agriculture Makurdi, Makurdi, Nigeria \\ Email address: \\ akiishimo@yahoo.com (M. Akiishi), bcisikwue@gmail.com (B. C. Isikwue), alexgbeh@yahoo.com (A. A. Tyovenda) \\ ${ }^{*}$ Corresponding author
}

\section{To cite this article:}

Moses Akiishi, Bernadette Chidomnso Isikwue, Alexander Aondongu Tyovenda. Determination of Geothermal Energy Sources in Masu Area Northeastern Nigeria Using Spectral Analysis of Aeromagnetic Data. International Journal of Energy and Environmental Science.

Vol. 3, No. 5, 2018, pp. 89-98. doi: 10.11648/j.ijees.20180305.11

Received: September 28, 2018; Accepted: October 16, 2018; Published: November 9, 2018

\begin{abstract}
The incessant power outage and power rationing in Nigeria has affected the economic development, hence the need to seek for other sources of electricity generation such as geothermal energy which is environmentally friendly and renewable. The wide range of geologic formations in the north-eastern Nigeria provides an avenue for exploration of geothermal energy. Hence, this work carries out an investigation of Curie point depth, geothermal gradient as well as heat flow in Masu, which is located within Nigerian sector of Chad Basin (lat. $12^{\circ} 00^{\prime}$ to $13^{\circ} 00^{\prime} \mathrm{N}$ and long. $12^{\circ} 30^{\prime}$ to $14^{\circ} 00^{\prime} \mathrm{E}$ ) using spectral analysis. Application of minimum curvature in gridding the total magnetic field intensity data was done using the Oasis Montaj 6.4.2 software. First order polynomial fitting was applied in Regional-residual separation. The Curie point depth obtained ranges from 12.233 to $16.184 \mathrm{~km}$ with an average of $13.993 \mathrm{~km}$, the geothermal gradient of the area varies from 35.838 to $47.413^{\circ} \mathrm{C} / \mathrm{km}$, with an average of $41.821^{\circ} \mathrm{C} / \mathrm{km}$, while the heat flow ranges from 89 to $117.80 \mathrm{mWm}^{-2}$, with an average of $104.551 \mathrm{mWm}^{-2}$. The $2 \mathrm{D}$ contour maps reveal that the Curie point depth is lowest in the southeast and increases towards the northwest, while the geothermal gradient and heat flow on the other hand are highest in the southeast and decrease towards northwest. The high geothermal gradient and heat flow values in the area are indications that the area might be suitable for geothermal energy generation as an alternative power supply in the area and in the country at large.
\end{abstract}

Keywords: Chad Basin, Geothermal Energy, Geothermal Gradient, Heat Flow, Alternative Power Supply

\section{Introduction}

The issue of power generation has become a necessity, since technology and science applications, which are the major determinants of economic development depend largely on power supply. This is because most of the machines and electrical appliances used in the industries, offices and at homes need power supply for their operation. Power generation is a major challenge to many nations including Nigeria. The major source of power generation in Nigeria is hydro electricity generation. This type of power generation may not be able to generate sufficient power all through the year, since it depends on the amount of water available in the dam, which drives the turbines that generate the electricity. Meanwhile, the availability of water depends on two distinct climatic seasons; these are rainy and dry seasons. During the dry season, water is normally inadequate in the dam; hence electricity generation via hydro is usually low. This situation could lead to incessant power outage or power rationing and, thus could affect the economic development of the country.

The rapid industrialization and population increase in Nigeria demand for uninterrupted electricity supply, in addition the declining in the reserves of fossil fuels and environmental constraints demand for alternative sources of energy such as geothermal energy, which is environmentally friendly and renewable. This energy is in the form of heat and is generated in the Earth's subsurface as a result of decay of naturally occurring radioactive isotopes. Geothermal plants convert geothermal resources into electricity [1]. This could be used to augment the nation's source of power 
generation and thus could alleviate the problem of power shortage in the country. Similarly, it will reduce the over dependence on fossil fuel and its attendant negative environmental effect. Geothermal resources are present everywhere beneath the Earth's subsurface, although vary in concentration from one geological province to another. Curie Point Depth is the depth at which the dominant magnetic mineral in the crust losses its ferromagnetic state due to increasing temperature [19]. Curie point depth greatly depends on the geologic conditions of the area under consideration and is shallower in volcanic and geothermal field $[4,35]$. This depth is assumed to be the depth for the geothermal source (magmatic chamber), where most geothermal reservoir tap their heat [11]. Assessment of variations of the Curie isotherm of an area can provide valuable information about the regional temperature distribution at depth and the concentration of subsurface geothermal energy [36]. Measurements have shown that a region with significant geothermal energy is characterized by an anomalous high temperature gradient and heat flow [36]. Therefore, this research work is aimed at investigating the Curie point depth, geothermal gradient as well as heat flow in Masu, which will enable the determination of areas with geothermal energy.

Some geothermal works have revealed that Nigerian sector of Chad basin has high prospect for geothermal resources [12, 4-6, 10, 15-17, 20-21, 23, 29]. However, these works were based on wire line logs from oil wells and lower resolution land magnetic data. These could be restricted in some areas and might have provided information at discrete locations. In addition, some of the works combined magnetic data of Masu with other towns. This may not provides good result, since geologic conditions vary from place to place. Therefore, there is need to investigate the geothermal resources in Masu. This will boost the power sector of Nigeria and, hence revamp our economy that is badly affected by shortage of power generation.

\section{Location and Geology of the Study Area}

The study area is located in Nigerian sector of Chad Basin, which lies within latitude $12^{\circ} 00^{\prime}$ to $13^{\circ} 00^{\prime}$ North and longitude $12^{\circ} 30^{\prime}$ to $14^{\circ} 00^{\prime}$ East (Figure 1). Nigerian sector of Chad basin is part of Chad basin which lies within a vast area of central and west Africa at an elevation between 200 and $500 \mathrm{~m}$ above sea level and covers approximately 230,000 $\mathrm{km}^{2}$ [3]. It is the largest area of inland drainage in Africa and extends into parts of the republic of Niger, Chad, Cameroon, Nigeria and Central Africa [7-8, 18]. The Nigerian Chad Basin is about one tenth of the basin and has a broad sediment-filled depression spanning north eastern Nigeria and adjoining parts of the Republic of Chad.

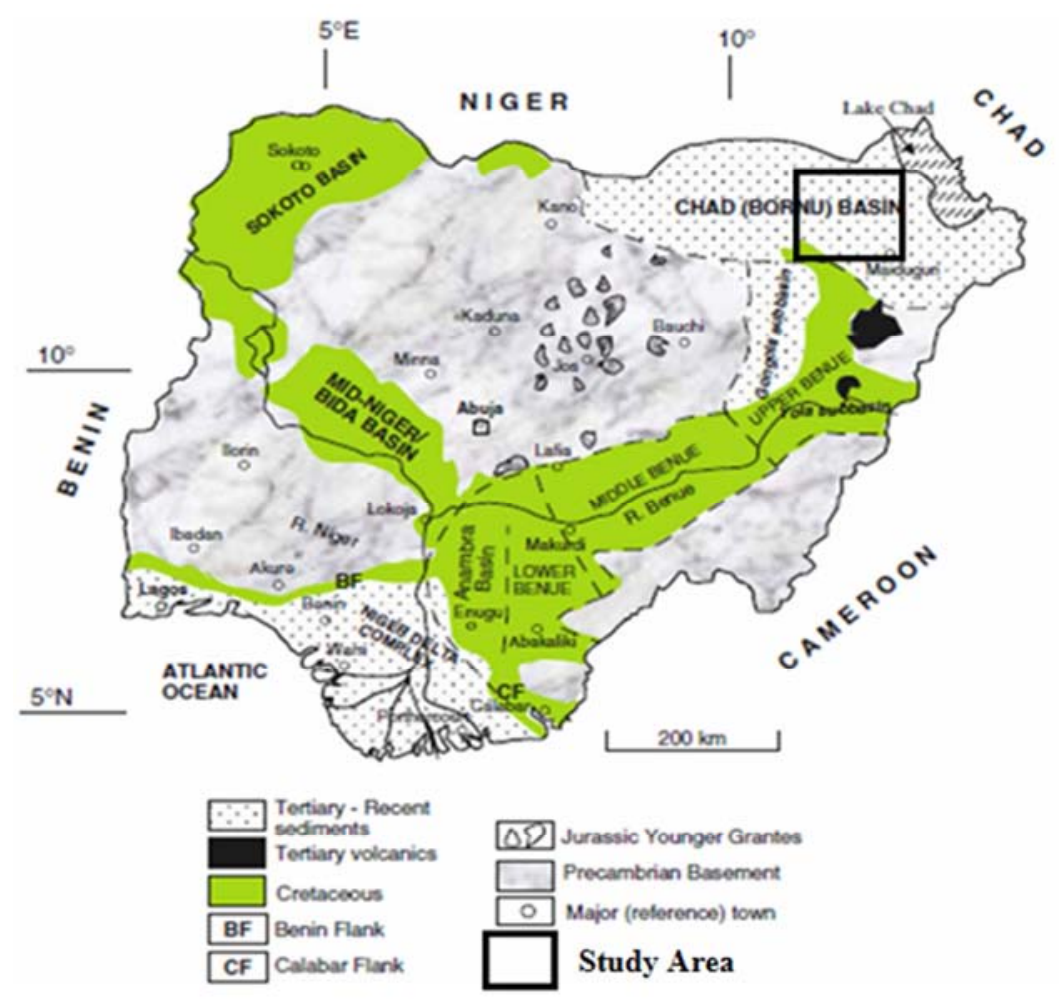

Figure 1. The Map of Nigeria Showing the Location of Chad Basin (Adapted from [24]).

The area generally is endowed with rock mineral base resources such as clay, salt, limestone, kaolin, iron ore, uranium, mica etc [3]. The sedimentary rocks of the area have cumulative thickness of over $3.6 \mathrm{~km}$ and the rocks consist of thick basal continental sequence overlain by transitional beds followed by a thick succession of quaternary Limnic, fluviatile and eolian sand, clay etc [26].

The stratigraphic sequence shows that Chad, Kerri-Kerri 
and Gombe formations have an average thickness of 130 to $400 \mathrm{~m}$. Below this formations are the Fika shale with a dark grey to black in colour, with an average thickness of $430 \mathrm{~m}$. Others are Gongila and Bima formations with average thicknesses of 320 and $3500 \mathrm{~m}$, respectively [26-28].

\section{Source of Data}

The high resolution airborne magnetic and gravity data used for this study were obtained from Nigerian Geological Survey Agency (NGSA). The airborne gravity data were obtained in 2013 using GRACE GRAVITY MODEL Sensor onboard 2 satellites by National Aeronautics and Space Administration (NASA) and German Aerospace Center, while the aeromagnetic data were obtained using a $3 \mathrm{x}$ Scintrex CS2cesium vapour magnetometer by Fugro Airborne Surveys in 2009. The airborne magnetic survey was carried out at $80 \mathrm{~m}$ elevation along flight lines spaced $500 \mathrm{~m}$ apart. The flight line direction was $135^{\circ}$, while the tie line direction was $225^{\circ}$. A correction based on the international Geomagnetic Reference Field (IGRF) 2010 was applied.

\section{Theory of Spectral Analysis}

Spectral analysis is the process of calculating and interpreting the spectrum of potential field data. It has been used extensively over the years to derive depth to certain geological features or the Curie isotherm [9, 32-33]. The spectral depth method is based on the principle that a magnetic field measured at the surface can be considered as an integral of magnetic signature from all depths [31]. The Discrete Fourier Transform is the mathematical tool for spectral analysis and applied to regularly spaced data such as the aeromagnetic data. A Fast Fourier Transform (FFT) algorithm computes the Discrete Fourier Transform (DFT) of a sequence, or its inverse. The Fourier Transform is represented mathematically as [30]:

$$
\mathrm{Y}_{\mathrm{i}}(\mathrm{x})=\sum_{\mathrm{n}=1}^{\mathrm{N}}\left[\mathrm{a}_{\mathrm{n}} \cos \left(\frac{2 \pi n x_{\mathrm{i}}}{\mathrm{L}}\right)+\mathrm{b}_{\mathrm{n}} \sin \left(\frac{2 \pi n \mathrm{x}_{\mathrm{i}}}{\mathrm{L}}\right)\right]
$$

$Y_{i}(x)$ is the reading at $x_{i}$ position, $L$ is length of the crosssection of the anomaly, $\mathrm{n}$ is harmonic number of the partial wave number, $\mathrm{N}$ is number of data points, $\mathrm{a}_{\mathrm{n}}$ is real part of the amplitude spectrum and $b_{n}$ is imaginary part of the amplitude spectrum; for $\mathrm{i}=0,1,2,3, \ldots, \mathrm{n}$.

The logarithms of the energy spectrum ( $\log E)$ are plotted against the domain frequency. Two linear segments are drawn from each graph; and their gradients $(\mathrm{m})$ are used to estimate the centroid depth $\left(Z_{o}\right)$, the depth to top boundary $\left(Z_{t}\right)$, Curie point depth, geothermal gradient $\left(\mathrm{Z}_{\mathrm{b}}\right)$ and heat flow $(\mathrm{q})$ using the relations as shown in equations $3-7$ [12-13, 23-24, $34-35,37]$.

$$
\begin{gathered}
\text { Slope }\left(\mathrm{m}_{1}, \mathrm{~m}_{2}\right)=\frac{\text { Log Energy }}{\text { Frequency }} \\
\mathrm{Z}_{\mathrm{o}}=-\frac{\mathrm{m}_{1}}{2 \pi}
\end{gathered}
$$

$$
\begin{gathered}
\mathrm{Z}_{\mathrm{t}}=-\frac{\mathrm{m}_{2}}{2 \pi} \\
\mathrm{Z}_{\mathrm{b}}=2 \mathrm{Z}_{\mathrm{o}}-\mathrm{Z}_{\mathrm{t}} \\
\frac{\mathrm{dT}}{\mathrm{dz}}=\frac{\theta}{\mathrm{z}_{\mathrm{b}}} \\
\mathrm{q}=\lambda\left[\frac{\theta}{\mathrm{z}_{\mathrm{b}}}\right]
\end{gathered}
$$

$\mathrm{m}_{1}$ and $\mathrm{m}_{2}$ are slopes, while $\mathrm{Z}_{\mathrm{o}}, \mathrm{Z}_{\mathrm{t}}, \mathrm{Z}_{\mathrm{b}}, \frac{\mathrm{dT}}{\mathrm{dz}}$ and $\mathrm{q}$ are centroid depth, depth to top boundary, Curie point depth, geothermal gradient and heat flow respectively. $\lambda$ is given as $2.5 \mathrm{Wm}^{-1} /{ }^{\circ} \mathrm{C}$ known as the average subsurface thermal conductivity and $\theta$ is the Curie temperature, for magnetite, $\theta=$ $580^{\circ} \mathrm{C}$ The negative sign (-) indicates depth to the subsurface

\section{Methods}

The total magnetic intensity data were imported into Oasis Montaj 6.4 software and were subsequently gridded using minimum curvature. These gridded data were further used to produce the total magnetic intensity maps. The regional residual separation was carried out by first order polynomial fitting. The residual values of magnetic anomalies were used to produce the residual magnetic intensity anomaly map.

\section{Curie Point, Geothermal Gradient and Heat Flow Estimations}

The residual magnetic map was divided into nine (9) equal spectral cells using the filtering tool of the Microsoft excel software. Each profile covers a square area of 18.33 by 18.33 km. Fast Fourier Transform (FFT) technique (equation 1) was employed in Microsoft (MS) excel program to transform the magnetic data into the radial energy spectrum for each block. The average radial energy spectra was calculated and displayed in a logarithm of energy versus frequency. The slopes obtained from equation 2 were substituted into equations 3 and 4 to estimate centroid depth and depth to top boundary $\left(Z_{o}\right.$ and $\left.Z_{t}\right)$ respectively, for each of the nine spectral cells. These depth values were further substituted into equation 5 to generate Curie point depth. These Curie point depth values were put into equation 6 to generate the geothermal gradient of the area. Finally, the heat flow was obtained using equation 7.

\section{Results}

Figures 2 shows the total magnetic intensity map, while Figure 3 gives the residual magnetic map divided into 9 equal spectra blocks for the estimation of geothermal parameters. On the other hand, Figures 4 and 5 give the spectral plots of logarithm of energy against frequency for blocks 1-4 and 5-9 respectively. The estimated values of Curie point depth, geothermal gradients and heat flow of the area are recorded on Tables 1. Finally, Figure 6 presents the contour maps of the geothermal parameters in the area. 


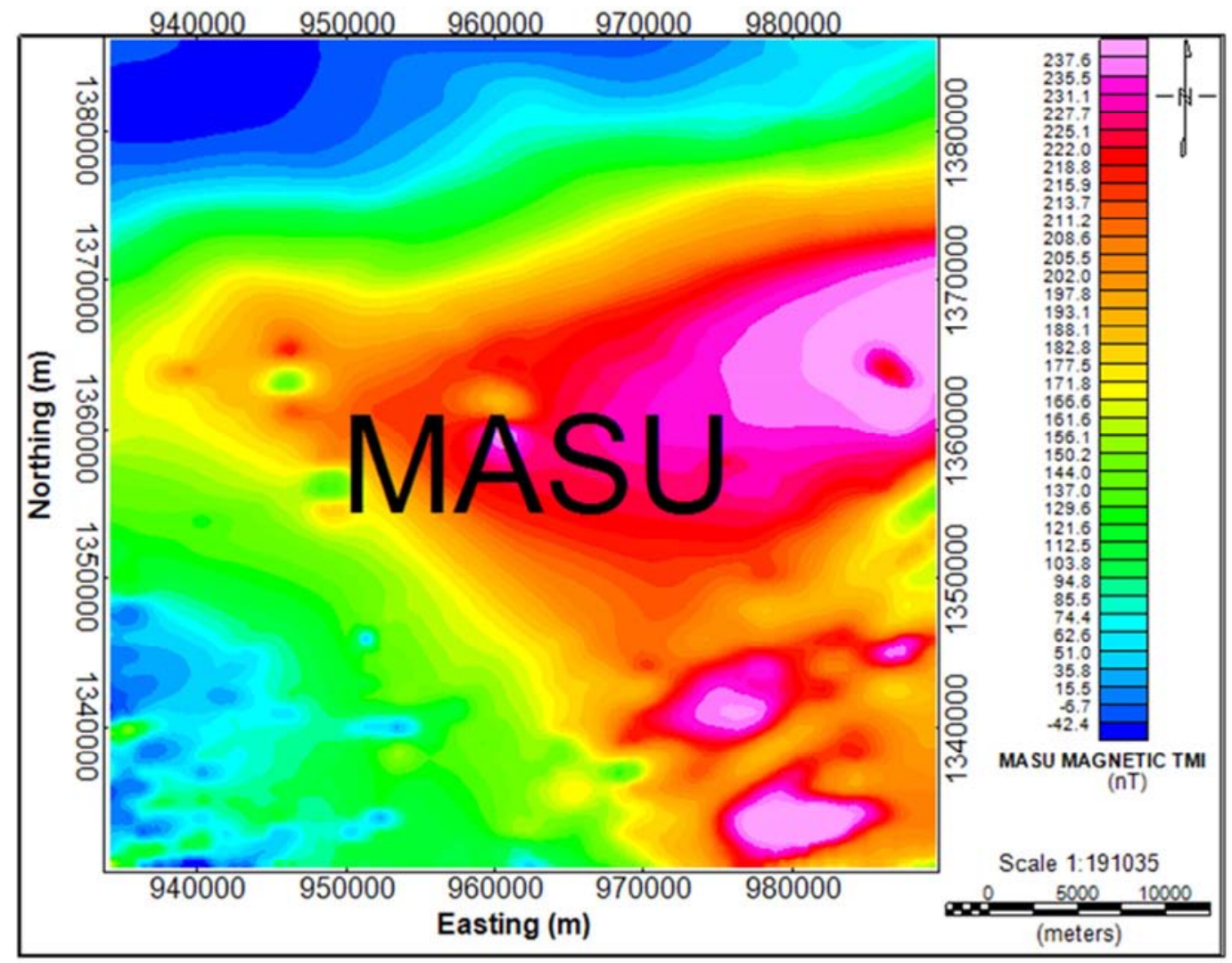

Figure 2. Total magnetic intensity map of the study area.

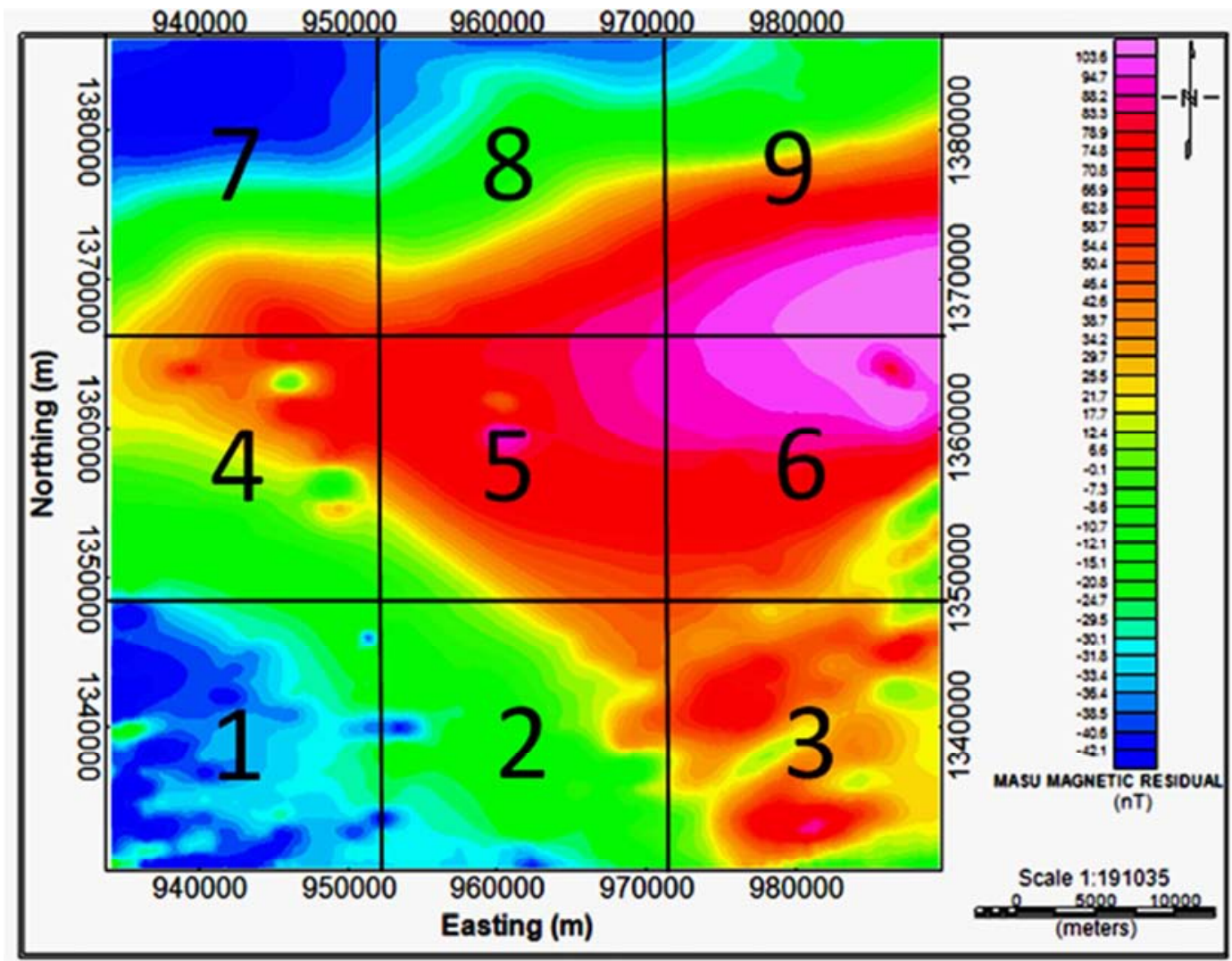

Figure 3. Division of residual magnetic map into 9 Spectral cells for Estimation of geothermal parameters in the study area. 

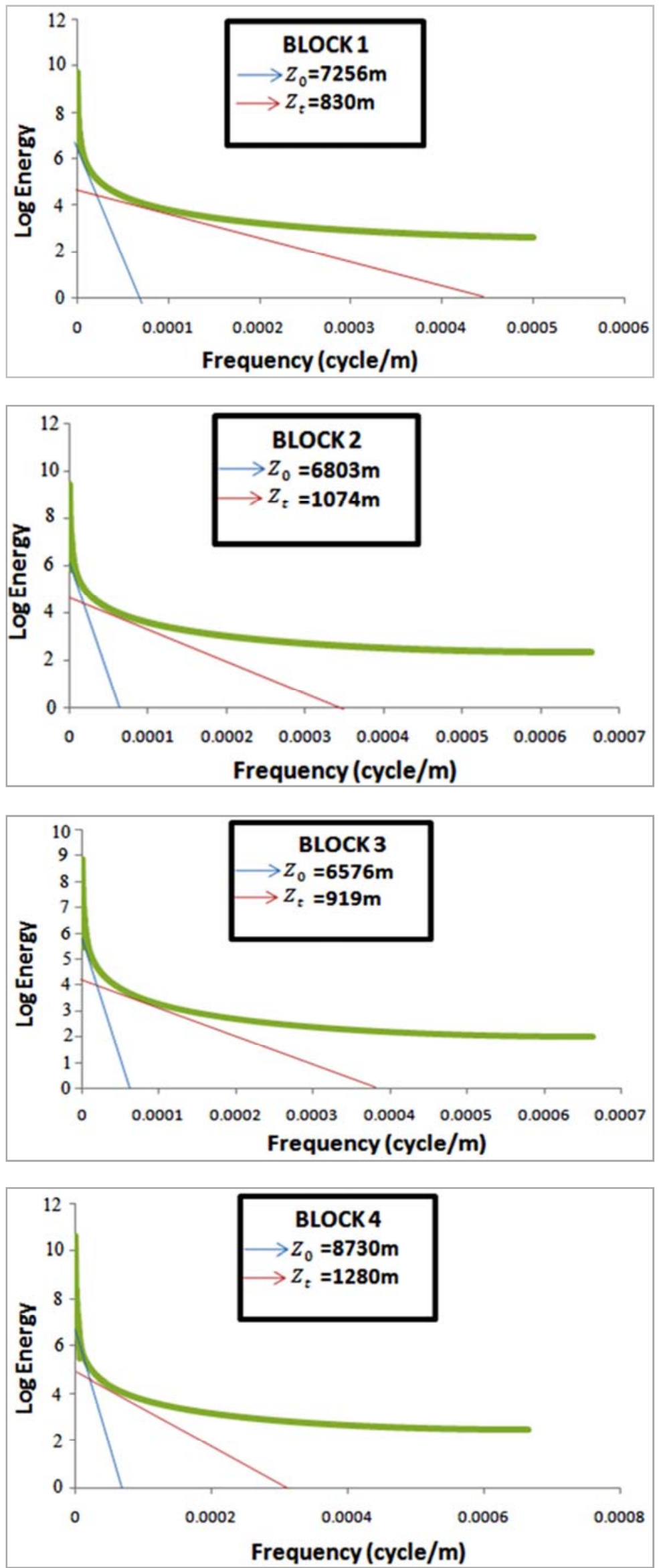

Figure 4. Spectral Plots of log of Energy against Frequency (cycle per meter) for blocks 1- 4. 

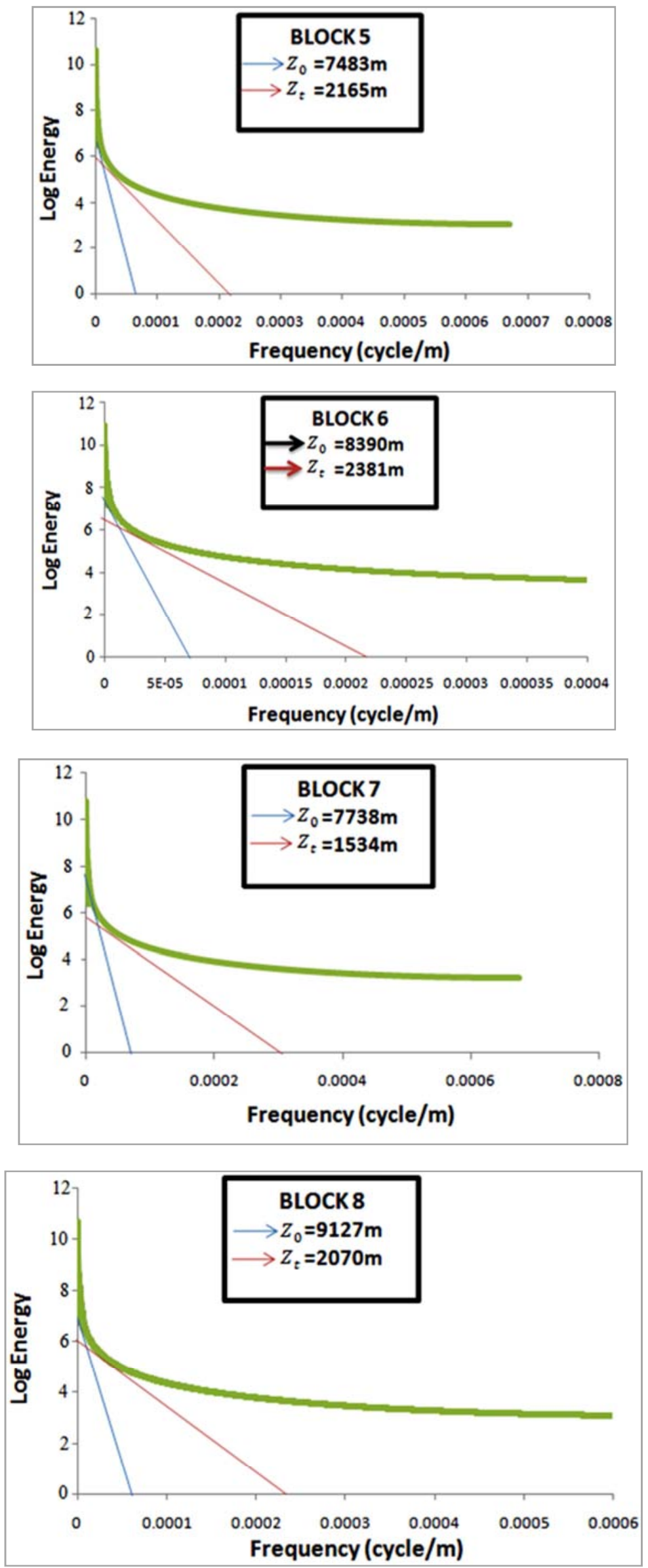


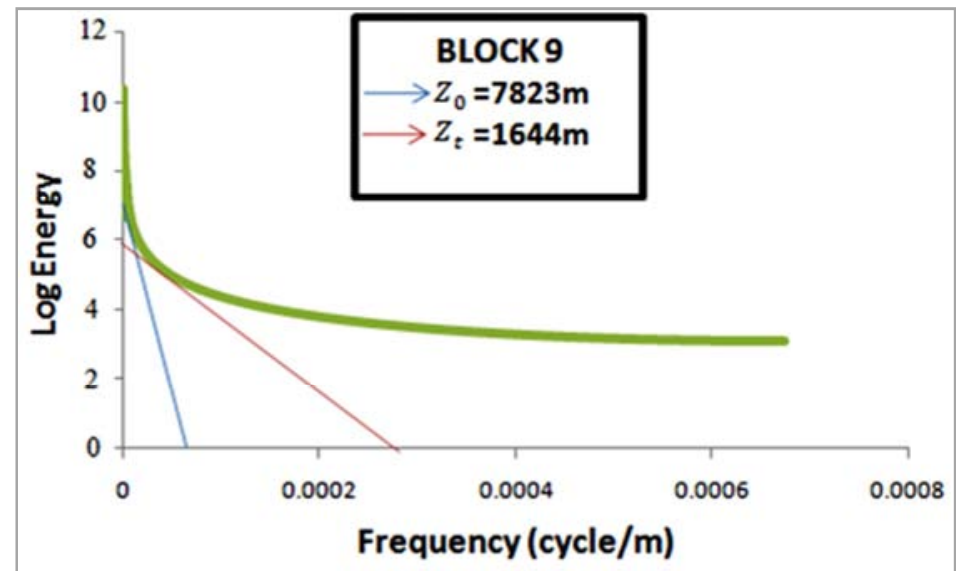

Figure 5. Spectral Plots of log of Energy against Frequency (cycle per meter) for blocks 5- 9.

Table 1. Estimated values of Curie depth, Geothermal gradient and Heat flow in the area.

\begin{tabular}{|c|c|c|c|c|c|}
\hline Spectral Blocks & Depth to Centroid $\left(Z_{0}\right)$ in $\mathbf{k m}$ & $\begin{array}{l}\text { Depth to top boundary } \\
\left(\mathrm{Z}_{\mathrm{t}}\right) \text { in } \mathrm{km}\end{array}$ & Curie Depth $\left(\mathbf{Z}_{b}\right)$ in km & $\begin{array}{l}\text { Geothermal } \\
\text { Gradient }\left(\frac{\mathrm{dT}}{\mathrm{dz}}\right)^{\circ} \mathrm{C} / \mathbf{k m}\end{array}$ & $\begin{array}{l}\text { Heat Flow(q) } \\
\text { mWm }^{-2}\end{array}$ \\
\hline 1 & 7.256 & 0.830 & 13.682 & 42.391 & 105.979 \\
\hline 2 & 6.803 & 1.074 & 12.532 & 46.282 & 115.704 \\
\hline 3 & 6.576 & 0.919 & 12.233 & 47.413 & 118.532 \\
\hline 4 & 8.730 & 1.280 & 16.180 & 35.847 & 89.617 \\
\hline 5 & 7.483 & 2.165 & 12.801 & 45.309 & 113.272 \\
\hline 6 & 8.390 & 2.381 & 14.399 & 40.281 & 100.701 \\
\hline 7 & 7.738 & 1.534 & 13.942 & 41.601 & 104.002 \\
\hline 8 & 9.127 & 2.070 & 16.184 & 35.838 & 89.595 \\
\hline 9 & 7.823 & 1.644 & 14.002 & 41.423 & 103.557 \\
\hline AVERAGE & & & 13.995 & 41.821 & 104.551 \\
\hline
\end{tabular}

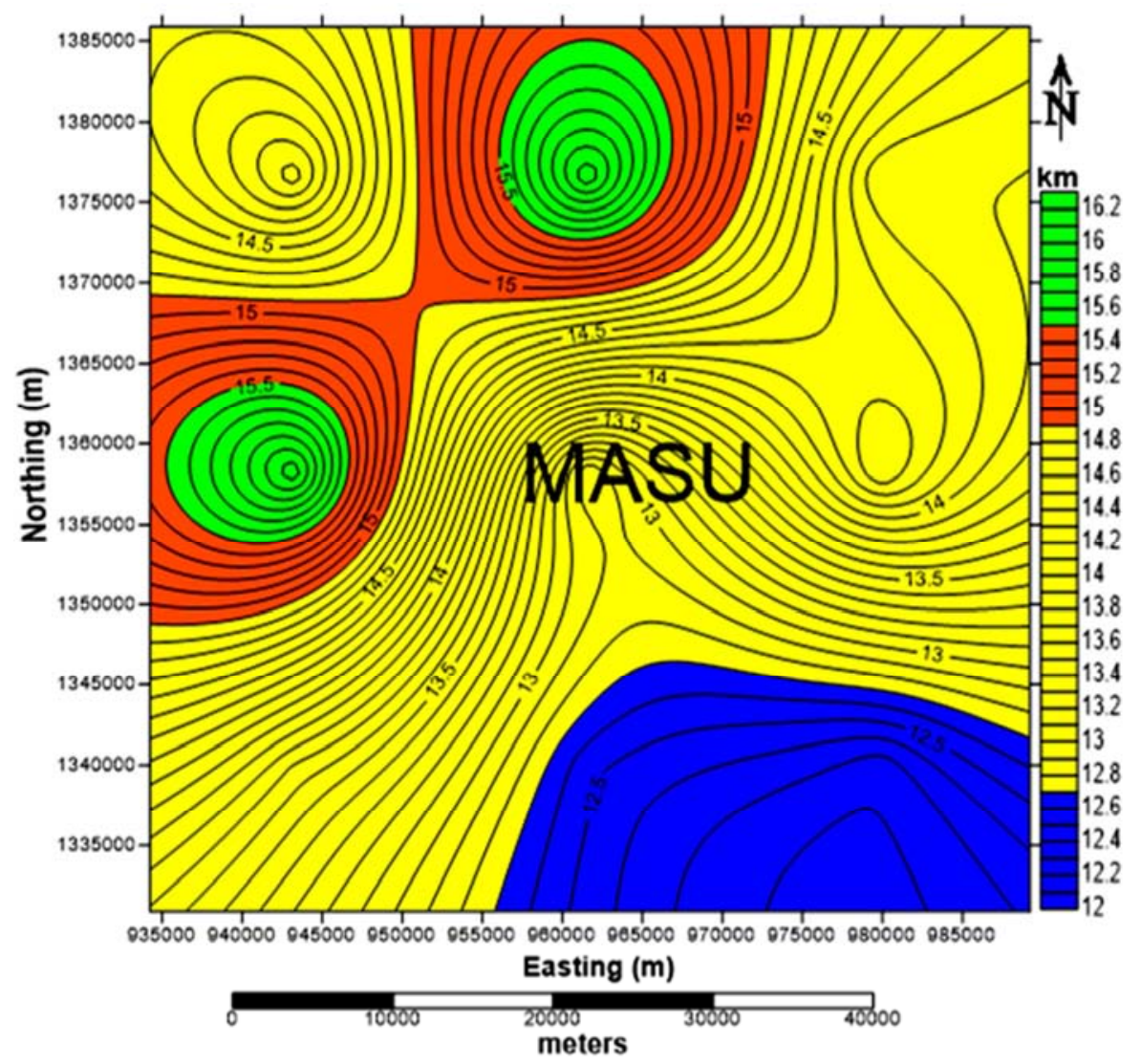

(a) 


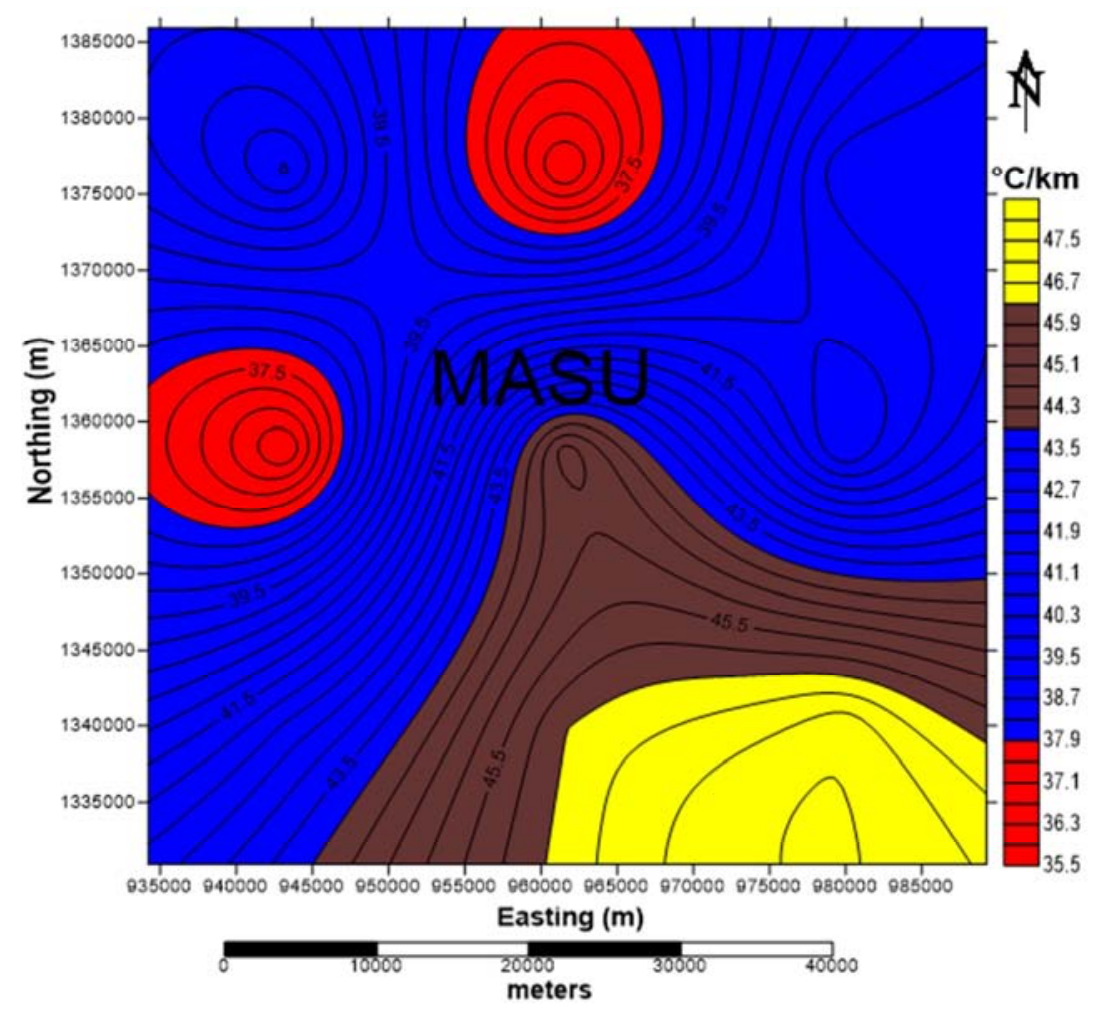

(b)

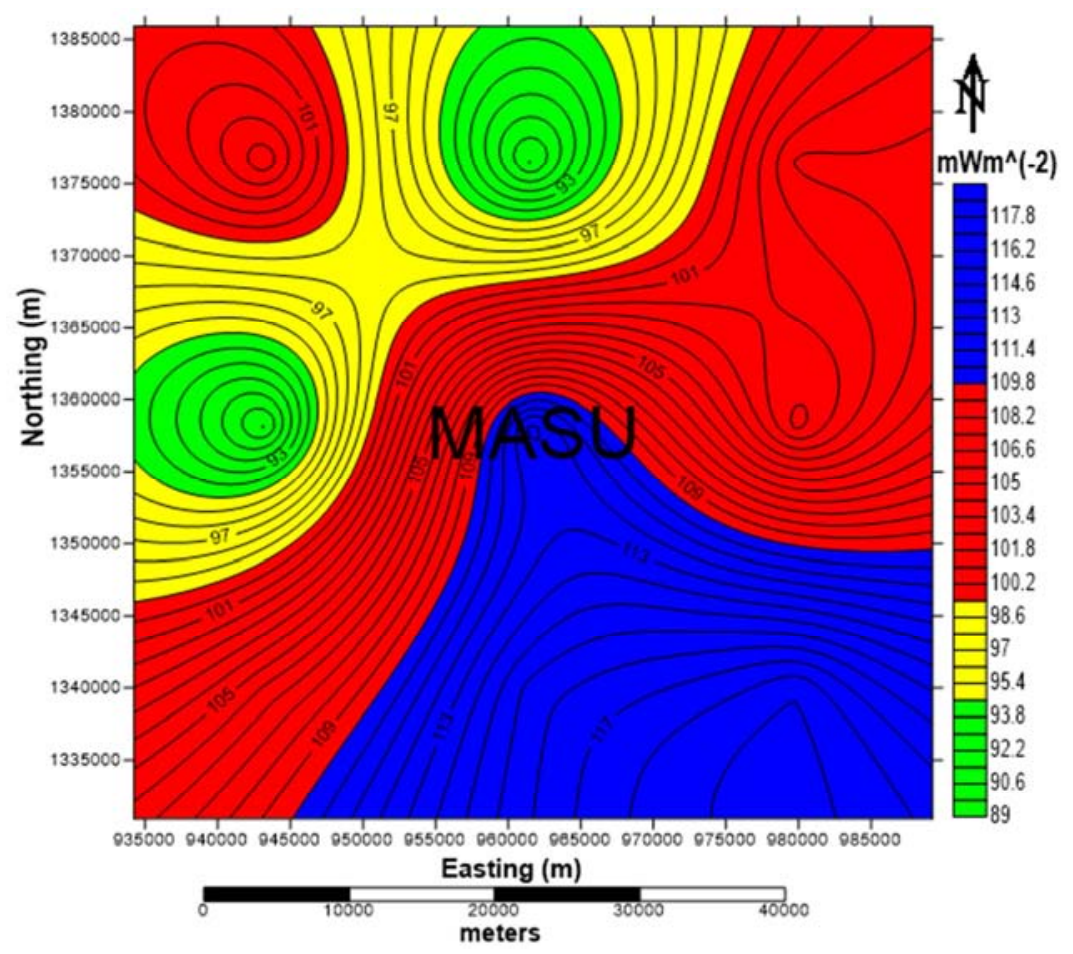

(c)

Figure 6. Contour maps of geothermal parameters in the area showing: (a) Curie point depth, (b) Geothermal Gradient and (c) Heat Flow.

\section{Discussion}

From the qualitative interpretation (Figure 2), it is noticed that the magnetic anomalies of the area range from- 42.4 to $237.6 \mathrm{nT}$. The area is marked by the high (pink and red colours) and low (blue colour) magnetic signatures. Consequently high magnetic intensity are noticed in the central and eastern parts of the study area, while, the northern and southwestern parts of the area are marked by low magnetic intensity. The variation in magnetic field intensity 
could be as a result of degree of strike, variation in depth, difference in magnetic susceptibility, differences in lithology, dip and plunge [25].

On the other hand, observation from Table 1 indicates that the calculated Curie point depths in the area range from 12.23 to $16.184 \mathrm{~km}$, with an average depth of about $14.0 \mathrm{~km}$. The 2D contour Curie depth map of the area (Figure 6a) shows that the deepest Curie depth is located in the north and western parts of Masu, while the shallowest Curie depth is observed in the southern part of the area. The deepest Curie point depth could be as a result of thick sediments, while the shallowest Curie point depth in the area could be due to the intrusion of igneous rocks or magmatic materials. The geothermal gradient of the area ranges from 35.84 to $47.41^{\circ} \mathrm{C}$ $/ \mathrm{km}$, with an average of $41.82^{\circ} \mathrm{C} / \mathrm{km}$. Area with highest geothermal gradient is observed in the southern part of Masu and decreases towards the central region, while the lowest geothermal gradient is located in the north and western parts of the area (Figure $6 \mathrm{~b}$ ). Table 1 indicates that the heat flow in the area varies from 89.62 to $118.53 \mathrm{mWm}^{-2}$, with an average heat flow of $104.55 \mathrm{mWm}^{-2}$. The highest heat flow is located in the south and decreases towards the central region of the area, while the lowest heat flow is seen in the north and western parts of the area (Figure 6c).

Critical observations from values in Table 1 show that the heat flow and geothermal gradient increase as the Curie depth decreases. This trend agrees with the results obtained by another researcher who estimated an average Curie depth in Wikki Warm Spring, located in parts of Benue basin, which links up the Chad Basin in the north to be10.72 km, with an average thermal gradient of $54.11^{\circ} \mathrm{C} / \mathrm{km}$ and average heat flow values of $135.28 \mathrm{mWm}^{-2}$ [2]. It was reported that heat flow close to $60 \mathrm{mWm}^{-2}$ is required for considerable generation of geothermal energy, while values ranging from 80 to $100 \mathrm{mWm}^{-2}$ and above indicate anomalous geothermal condition [22]. Areas observed with high heat flow values correspond to active volcanic and metamorphic rocks and can also be governed by deep magnetic mass that is yet to complete its cooling in association with young volcanism and faulted structures. Similarly, according to some authors, regions of high geothermal gradient could lead to the generation of hydrocarbon at shallow depth, while regions of low geothermal gradient may not be viable for hydrocarbon exploration, except at a greater depth [14]. This is because geothermal gradient plays a major role in hydrocarbon generation; along with several other factors such as rapid burial of organic debris in oxygen-depleted environment.

\section{Conclusion}

The qualitative and quantitative interpretation of aeromagnetic data covering Masu in the Nigerian sector of Chad Basin has been carried out. The qualitative interpretation reveals that the magnetic anomalies of the area range from -42.4 to $237.6 \mathrm{nT}$. The area is marked by the high (pink and red colours) and low (blue colour) magnetic signatures. Consequently high magnetic intensity are noticed in the central and eastern parts of the study area, while, the northern and southwestern parts of the area are marked by low magnetic intensity. The Curie point depth obtained varies between 12.24 and $16.18 \mathrm{~km}$, with average of $14.0 \mathrm{~km}$. Its map defines region of deepest curie depth in the north and western parts of Masu, while the shallowest Curie depth is observed in the southern part of the area. The geothermal gradient ranges from 35.84 to $47.41{ }^{\circ} \mathrm{C} / \mathrm{km}$, with an average of $41.82^{\circ} \mathrm{C} / \mathrm{km}$ and is high in the southern part of Masu and decreases towards the central region, while the lowest geothermal gradient is located in the north and western parts of the area. Its corresponding heat flow varies between 89.62 and118.53 $\mathrm{mWm}^{-2}$, with an average of104.55 $\mathrm{mWm}^{-2}$. Highest heat flow is located in the south and decreases towards the central region of the area, while the lowest heat flow is seen in the north and western parts of the area. The heat flow and geothermal gradient increase as the Curie depth decreases, this is equally observed in the previous research works. The high geothermal gradient and at flow values obtained in the area are indications that the area might be suitable for geothermal energy generation. Therefore, geothermal power plant could be sited in the area.

\section{Acknowledgements}

Nigerian Geological Survey Agency Abuja is acknowledged for making the data used in this work available.

\section{References}

[1] Abdullahi, B. U, Rai, J. K., Olaitan, O. M. and Musa, Y. A. ( 2014) A Review of theCorrelation between Geology and Geothermal Energy in North-Eastern Nigeria IOSR Journal of Applied Geology and Geophysics, Vol. 2 No3 pp 74-83.

[2] Abraham, E. M, Oband, E. G, Chukwu, C. G and Chukwu, M. O (2015). Estimating depth to the bottom of magnetic sources at Wikki Warm Spring region, northeastern Nigeria, using fractal distribution of sources approach Turkish Journal of Earth Sciences, pp 1-19.

[3] Ajana, O., Udensi. E. E., Momoh, M., Rai, J. K. and Muhammad, S. B. (2014). Spectral Depths Estimation of Subsurface Structures in Parts of Borno Basin, North eastern Nigeria, using Aeromagnetic Data Journal of Applied Geology and Geophysics. Vol2 No2 pp:55-60.

[4] Aliyu, A. Salako, K. A. Adewumi, T. and Mohammed, A.(2018). Interpretation of High Resolution Aeromagnetic Data to Estimate the Curie Point Depth Isotherm of Parts of Middle Benue Trough and North-East, Nigeria Physical Science International Journal Vol 17 No 3.

[5] Ali, S. and Orazulike, D. M. (2010). Well log-Derived Radiogenic Heat Production in the Sediments of the Chad Basin, North -East Nigeria, Journal of Applied Science Vol 2 pp 1-9.

[6] Anakwuba, E. K. and Chinwuko, A. I. (2015). One Dimensional Spectral Analysis and Curie Depth Isotherm of Eastern Chad Basin, Nigeria. Journal of Natural Sciences Research, Vol5 No19, pp 14-22. 
[7] Avbovbo. A. A.; Ayoola, E. O. and Osahon, G. A. (1986). Depositional and Structural Styles in Chad Basin of Nigeria. Bulletin American Association Petroleum Geologists,. Vol 70 No 121, pp 1787-1798.

[8] Barber, W. (1965) Pressure Water in the Chad formation of Borno and Dikwa Emirates, NE Nigeria. Bulletin Geological Survey of Nigeria. 35 pp138.

[9] Blakely, R. J. (1988). Curie Temperature Analysis and Tectonic Implications of Aeromagnetic Data from Nevada. Journal of Geophysical Research. Vol 93No B10 pp 11817 11832.

[10] Chanda, M. S, Obaj, U, Lar, A and Moumouin, A. (2007). Petroleum Geochemistry of Kuchali Continental journal of Earth Science Vol 1 pp18-24.

[11] Eletta, B. E. and Udensi, E. E. (2012). Investigation of the Curie Depth Isotherm from the Magnetic fields of Eastern Sector of Central Nigeria. Geosciences. Vol2 No4, pp 101106.

[12] Frost, B. R. and Shive, P. N. (1986). Magnetic mineralogy of the lower continental crust. Journal of Geophysical Research, Vol 91 No B6, pp 6513-6521.

[13] Hinze, W. J.; VonFrese, R. B. and Saad, A. H. (2013). Gravity and Magnetic Exploration. Cambridge University Press, 512.

[14] Hsien- Hsiang, H, Chieh-Hung Chen, Pei-Ying, L. and HorngYuan, Y. (2014). Curie point depth from spectral analysis of magnetic data in Taiwan. Journal of Asian Earth Science Vol 90, pp 26-33.

[15] Kasidi, S. and Nur, A. (2013). Estimation of Curie Point Depth, Heat Flow and Geothermal Gradient Inferred from Aeromagnetic Data over Jalingo and Evirons North-Eastern Nigeria. International Journal of Physical Sciences. Vol3 No $2,:$ pp 27-39.

[16] Kwaya, Y. M, Kurowska, E. and Arabi, A. S. (2016a). Geothermal Gradient and Heat Flow in the Nigeria Sector of the Chad Basin, Nigeria. Computational Water, Energy, and Environmental Engineering, Vol 5, pp 70-78.

[17] Kwaya M. Y., Kurowska, E. and Arabi, A. S. (2016b). Dynamics of Geothermal Variability in the Nigerian Sector of the Chad B. Sustainable Energy Vo 14 No1, pp 28-33.

[18] Matheis, G. (1976). Short review of the geology of Chad Basin in Nigeria, Lagos, Nigeria: Elizabethan publication company, pp289-294.

[19] Nagata, T. (1961). Rock Magnetism, Maruzen, Tokyo. 350.

[20] Nwankwo, C. N., Anthony S., Ekine, P., Nwasu. K, and Leonard. I. (2012). Estimation of the Heat Flow Variation in the Chad Basin Nigeria. Journal of Applied Sciences Environmental Management,. Vol 4, pp28-34.

[21] Nwankwo, C. N. and Ekine, A. S. (2009). Geothermal Gradients in the Chad Basin, Nigeria from Bottom hole temperature Logs. International Journal of physical sciences. Vol4 No 12, pp777-783.

[22] Nwankwo, L. I. and Shehu, A. T. (2015). Evaluation of Curiepoint depths, geothermal gradients and near-surface heat flow from high-resolution aeromagnetic (HRAM) data of the entire Sokoto Basin. Journal of Volcanol Geothermal Research Vol30 No5, pp 45-55.

[23] Nwankwo, L I, Olasehinde, P I, Akoshile, C O (2011). Heat flow anomalies from then spectral analysis of Airborne Magnetic data of Nupe Basin, Nigeria. Asian J. Earth Sci. Vol 1 No1, pp 1-6.

[24] Obaje, N. G. (2009). Geology and Mineral Resources of Nigeria, Berlin Springer publishers, pp 1-203.

[25] Obiora, D. N., Ossai, M. N. and Okwohi, E. (2015). A Case Study of Aeromagnetic Data Interpretations of Nsukka Area, Enugu state, Nigeria for hydrocarbon Exploration. International Journal of Physical Science. Vol 10 No17, pp 503-519.

[26] Odebode, M. O. (2010) A handout on geology of Borno (Chad) Basin Northeastern Nigeria.

[27] Okosun, E. A. (1995) Review of Borno Basin. Journal of mining and geology Vol 31 No2, pp: 113-172.

[28] Okpikoro, F. E. and Olorunniwo, M. A. (2010). Seismic Sequence Architecture and Structural Analysis of NorthEastern, Nigeria Chad (Bornu) Basin, Journal of Earth Science 5(2): 1-9.

[29] Olaleye, N. and Amoo, A. (2014). Thermodynamic based resource classification of renewable Geothermal Energy in Nigeria Journal of Renewable and Sustainable Energy, pp 2230.

[30] Onwuemesi, A. G. (1997). One-Dimensional Spectral Analysis of Aeromagnetic Anomalies and Curie point Depth Isotherm in the Anambra Basin of Nigeria. Journal of Geodynamics Vol 23 No2, pp: 95-107.

[31] Rabeh, T. (2009). Prospecting for the Ferromagnetic Mineral Accumulations Using the Magnetic Method at the Eastern Desert, Egypt. Journal of Geophysics and Engineering 6 (4): 401-411.

[32] Spector, A., Grant, F. S., (1970). Statistical models for interpretation of aeromagnetic data. Geophysics, 35, 293-302.

[33] Shuey, R. T.; Schellinger, D. K.; Tripp, A. C, and Alley, L. B. (1977). Curie Depth Determination from Aeromagnetic Data Spectral Analysis. Geophysics Journal of the Royal Astronomical society. Vol 50 No1, pp 73-101.

[34] Stampolidis, A, Kane, I, Tsokas GN, Tsourlo, P (2005). Curie point depths of Albania inferred from ground total field magnetic data. Surveys in Geophysics. Vol 26, pp 461- 480.

[35] Tanaka A, Okubo Y, Matsubayashi O (1999). Curie point depth basedon spectrum analysis of the magnetic anomaly data in East and Southeast Asia. Tectonophysics Vol 306, pp $61-470$.

[36] Tselentis, GA (1991). An attempt to define Curie depth in Greece from Aeromagnetic and heat flow data. PAGEOPH, Vol 136 No1, pp:87-101.

[37] Turcotte, D. L. and Schubert, G. (1982). Geodynamics: Applications of continuum physics to geological problems. New York Cambridge University Press, pp 450. 